\title{
KUALITAS PELAYANAN KESEHATAN DI PUSAT KESEHATAN MASYARAKAT KEMBANG SERI KECAMATAN TALANG EMPAT KABUPATEN BENGKULU TENGAH
}

Oleh:

\section{YOKI APRIYANTI, EVI LORITA, YUSUARSONO}

\author{
Program Studi Administrasi Publik Fakultas Ilmu-Ilmu Sosial \\ Universitas Dehasen Bengkulu
}

\section{ABSTRAC}

$T$

This study aims to find out the quality of health services in Kembang Seri Public Health Center atTalang Empat Sub-District, Central Bengkulu Regency. This research is a qualitative research presented descriptively. The informants in this study amounted to 6 people consisting of key informants and principal informants. The data were collected by interviews, observation and documentation method. The technique data analysis used were data reduction, data presentation, and conclusion. Based on the results show that the quality of Health Services in the Kembang Seri of Talang Empat Sub-District of Central Bengkulu Regency is seen from the theory of service quality 1)The Reliability has done a good service but nurses are still not friendly in patient. 2) Responsiveness of nurses are ready and sufficiently skilled in treating patients but there are also nurses who are still arrogant and play their own cellphones while patients need service.3) Assurance of nurses are less friendly and polite to patients and nurses still distinguish services from rich patients and poor patients in terms of service but nurses are active in communicating with patients. 4) Empathy of nurse is easily contacted in every room that keeps and communicates with the patient ready to be called by the patient's family if needed. However, in terms of medicines and intravenous needles there is still a lack of availability. 5. Tangibles (Physical Facilities) seen from the building of Kembang Seri Public Health Center is good and medical equipment is sufficient.

Keywords: Quality of Health Services, Nurses / Midwives and Patients.

\section{PENDAHULUAN}

Pelayanan kesehatan merupakan hak dasar masyarakat yang harus dipenuhi sebagai salah satu upaya pemenuhan kebutuhan masyarakat sebagai warga Negara Indonesia. Puskesmas merupakan unit yang strategis dalam mendukung terwujudnya perubahan status kesehatan masyarakat menuju peningkatan derajad kesehatan yang lebih optimal. Mewujudkan derajad kesehatan yang optimal tentu diperlukan upaya pembangunan sistem pelayanan kesehatan dasar yang mampu memenuhi kebutuhan- kebutuhan masyarakat selaku konsumen dari pelayan kesehatan dasar tersebut.

Tujuan pembangunan kesehatan sebagai komitmen nasional dapat dilihat pada pasal 3 Undang-Undang Nomor 36 tahun 2009 (Undang-Undang Kesehatan) seperti berikut : "Pembangunan kesehatan bertujuan untuk meningkatkan kesadaran, kemauan, dan kemampuan hidup sehat bagi setiap orang agar terwujud derajat kesehatan masyarakat yang setinggitingginya, sebagai investasi bagi pembangunan sumber daya manusia yang produktif secara sosial dan 
ekonomis.'Dalam Undang-Undang Nomor 36 Tahun 2009 menjelaskan bahwa kesehatan adalah keadaan sehat, baik secara fisik, mental, spritual maupun sosial yang memungkinkan setiap orang untuk hidup produktif secara sosial dan ekonomis. Dan juga telah ditetapkan bahwa setiap orang berhak memperoleh pelayanan kesehatan.

Oleh karena itu, setiap elemen masyarakat baik individu, keluarga, berhak memperoleh pelayanan atas kesehatannya dan pemerintah bertanggung jawab mencanangkan, mengatur menyelenggarakan dan mengawasi penyelenggaraan kesehatan secara merata dan terjangkau oleh masyarakat. Salah satu bentuk upaya pemerintah dalam menyelenggarakan kesehatan kepada masyarakat maka di tiap kecamatan dibangun instansi pemerintah sebagai unit penyelenggara pelayanan kesehatan masyarakat, yakni Pusat Kesehatan Masyarakat atau yang biasa disebut Puskesmas. Puskesmas merupakan unit yang strategis dalam mendukung terwujudnya perubahan status kesehatan masyarakat menuju peningkatan derajad kesehatan yang lebih optimal. Pusat Kesehatan Masyarakat (Puskesmas) adalah fasilitas pelayanan kesehatan yang menyelenggarakan Peraturan menteri kesehatan republik Indonesia nomor 75 tahun 2014 tentang upaya kesehatan masyarakat dan upaya kesehatan perseorangan tingkat pertama, dengan lebih mengutamakan upaya promotif dan preventif, untuk mencapai derajat kesehatan masyarakat yang setinggitingginya di wilayah kerjanya. Dalam pelayanan rutinnya setiap hari.

Puskesmas Kembang Seri telah dilengkapi dengan berbagai unit pelayanan kesehatan dalam manangani keluhan pasien seperti Poli Umum, Poli Kia, Poli Usila, Poli Gigi, dari beberapa poli yang ada di Puskesmas penulis memilih pelayanan yang ada di Poli Umum dikarenakan pasien masih mengeluhkan pelayanan yang diberikan oleh
Puskesmas Kembang Seri. Pelayanan yang diberikan belum sesuai dengan ke inginan pasien salah satunya adalah kurang tanggapnya pegawai dalam melakukan penanganan pasien, banyaknya pasien yang tak bisa ditangani pengobatannya oleh puskesmas setempat karena keterbatasan sumberdaya manusia, sehingga hal ini berdampak pada daya tanggap yang kurang maksimal dari pemberi layanan kepada pasien yang datang. sehingga dapat menjadi masukan untuk peningkatan kualitas pelayanan kesehatan. Berdasarkan itu penelitian terhadap kualitas pelayanan kesehatan masyarakat (Puskesmas) di Desa Kembang Seri Kecamatan Talang Empat Kabupaten Bengkulu Tengah perlu dilakukan, agar pelayanan yang kurang optimal dapat diperbaiki dan pelayanan dengan nilai mutu terbaik dapat dipertahankan.

Puskesmas Kembang Seri selama tiga tahun terakhir yaitu pada tahun 2015 sampai dengan tahun 2017 menunjukan angka pasien pada tahun 2015 berjumlah 7.172 pasien, ditahun 2016 berjumlah 8.215 pasien, sedangkan ditahun 2017 berjumlah 7.523 pasien. Pada tahun 2016 angka pasien menunjukan adanya peningkatan yang cukup tinggi untuk berobat kepuskesmas dibandingkan tahun sebelumnya. Sedangkan tahun 2017 angka pasien yang berobat ke Puskesmas cenderung berkurang dari tahun 2016 lalu, hal ini disebabkan banyak faktor yang terdapat di Puskesmas Kembang Seri diantaranya kurang ramahnya pelayanan dipuskesmas, kurangnya alat medis. Dengan semakin berkurangnya kunjungan pasien pada tahun 2017 maka harus di tingakatkan pula kualitas pelayanan kesehatan baik dari fisik maupun non fisik. Dengan memperhatikan kondisi lapangan serta dukungan informasi yang peneliti dapatkan dari masyarakat Kabupaten Bengkulu Tengah, maka untuk menyingkapi kenyataan tersebut peneliti tertarik mengangkat permasalahan ini ke dalam penelitian. 


\section{METODE PENELITIAN}

Jenis penelitian yang digunakan oleh penulis adalah jenis kualitatif. Metode kualitatif adalah metode penelitian yang digunakan untuk meneliti untuk kondisi obyek yang alamiah, dimana peneliti yang menjadi instrumen kunci, teknik pengumpulan data dilakukan secara trianggulasi (gabungan), analisis data bersifat induktif, dan hasil penelitian kualitatif lebih menekankan makna dari pada generalisasi.

Dalam penelitian kualitatif peneliti menggunakan human instrumen untuk mengumpulkan data seperti bertanya, menganalisis, memotret, dan mengkonstruksi obyek yang diteliti menjadi lebih jelas dan bermakna yang bertujuan untuk membuat deskrips, gambaran secara sistematis, faktual dan akurat mengenai fakta-fakta, sifat-sifat serta hubungan antar fenomena yang diselidiki (Sugiyono, 2004;1).

\section{Informan Penelitian}

Informan dalam penelitian ini, penulis tentukan dengan metode purposive sampling, purposive sampling adalah teknik pengambilan sampel dengan pertimbangan tertentu (Sugiyono, 2012;216). Dengan menggunakan purposive sampling, diharapkan kreteria sampel yang diperoleh benar-benar sesuai dengan penelitian yang dilakukan dan mampu menjelaskan keadaan sebenarnya tentang objek yang diteliti. Keseluruhan informan dalam penelitian ini adalah sebanyak 6 (enam) orang informan penelitian, terdiri dari; 1) Informan kunci yaitu seseorang yang secara lengkap dan mendalam mengetahui informasi yang akan menjadi permasalahan dalam penelitian ini sebanyak 3 orang informan, 2) Informan pokok, yaitu masyarakat yang terlibat secara langsung dalam interaksi sosial yang diteliti dalam penelitian ini sebanyak 3 orang informan.

\section{Teknik Pengumpulan Data}

Pengumpulan data yang digunakan dalam penelitian ini adalah:

\section{a. Observasi (Pengamatan)}

Observasi atau pengamatan adalah suatu teknik pengumpulan data dengan cara melakukan pengamatan secara langsung ke lapangan terhadap objek yang diteliti. Dalam penelitian ini peneliti melakukan pengamatan secara langsung mengenai pelayanan kesehatan di puskesmas.

\section{b. Wawancara (interview)}

Menurut (Sugiyono, 2014). Peneliti menggunakan teknik wawancara dengan tujuan memperoleh data atau informasi yang dibutuhkan dalam penelitian langsung dari narasumber yang bersangkutan dan mengetahui tentang peristiwa tersebut, sehingga antara pertanyaan dan jawaban dapat diperoleh secara langsung dalam suatu konteks kejadian secara timbal balik. Perangkat pedoman wawancara yang akan digunakan memuat pertanyaan yang bersifat terbuka, wawancara bersifat terbuka dalam hal ini diharapkan akan memperoleh data sebanyak mungkin, dan mendalam agar data yang digali nantinya tidak terlalu melebar dari topik utama dan tujuan peneliti yang sebenarnya. Wawancara merupakan salah satu teknik pengumpulan data atau informasi dengan bertanya langsung kepada responden. Wawancara dalam penelitian ini digunakan untuk memperoleh data tentang Kualitas pelayanan kesehatan di Puskesmas Kembang Seri. Wawancara dilakukan langsung oleh peneliti untuk mengetahui dan mengungkapkan tentang pelaksanaan pelayanan publik dengan petugas bagian pelayanan umum, dan masyarakat yang berkunjung.

\section{c. Dokumentasi}

Teknik dokumentasi merupakan penelusuran dan perolehan data yang diperlukan melalui data yang telah tersedia (Hikmat, 2011:83). Teknik dokumentasi digunakan adalah dengan 
maksud untuk melengkapi hasil data yang diperoleh melalui teknik wawancara dan pengamatan yang telah dilakukan sebelumnya. Dokumentasi yang dilakukan pada penelitian ini dengan cara menyimpan berbagai kegiatan dalam penelitian yang berisi proses dan hasil penelitiannya melalui pengambilan gambar, serta dokumentasi.( Sugioyono:2014). Dokumentasi yaitu salah satu teknik pengumpulan data dengan cara mengambil gambar atau dokumendokumen untuk memperoleh data. Dokumen-dokumen yang dimaksud seperti : arsip-arsip dokumen kegiatan pelayanan kesehatan, foto-foto saat melakukan pelayanan kesehatan, serta data-data yang mengenai pelayanan kesehatan yang ada di puskesmas.

\section{Teknik Analisis Data}

Teknik yang digunakan untuk menganalisa data dalam penelitian ini mengacu pada teknik analisa data kualitatif. Menurut Sugiyono (2007) analisa data adalah proses mencari dan menyusun data yang diperoleh dari hasil wawancara, observasi dan dokumentasi sehingga dapat menjabarkan mana yang penting dan mana yang dipelajari dan mengambil kesimpulan. Analisis data dalam penelitian kualitatif dilakukan pada saat pengumpulan data berlangsung, setelah selesai pengumpulan data dalam periode tertentu. Pada saat wawancara, peneliti sudah melakukan analisis terhadap jawaban dari informan. Apabila jawaban yang diwawancarai setelah dianalisis terasa belum memuaskan, peneliti akan melanjutkan ke pertanyaan lagi, sampai tahap tertentu sehingga datanya sudah tidak jenuh. Aktivitas dalam menganalisis data kualitatif yaitu antara lain:

\section{Reduksi Data (Data Reduction)}

Reduksi data diartikan sebagai proses pemilihan pemusatan perhatian pada penyederhanaan, pengabstrakan, transformasi data kasar yang muncul dari catatan-catatan tertulis di lapangan. Laporan atau data yang diperoleh di lapangan akan dituangkan dalam bentuk uraian yang lengkap dan terperinci. Mereduksi data berarti merangkum, memilih hal-hal pokok, memfokuskan pada hal-hal yang penting, serta dicari tema dan polanya. Dengan demikian data yang telah direduksi akan memberikan gambaran yang jelas dan mempermudah peneliti untuk melakukan pengumpulan data selanjutnya. Data yang diperoleh dari lokasi penelitian dituangkan dalam uraian laporan lengkap dan terperinci dalam mereduksi data ini peneliti dipandu oleh tujuan yang ingin dicapai. Adapun tujuan utama dari penelitian kualitatif ini adalah untuk mengetahui temuan mengenai tema penelitian yaitu KualitasPelayanan Kesehatan Di Pusat Kesehatan Masyarakat (Puskesmas) Kembang Seri Kecamatan Talang Empat Kabupaten Bengkulu Tengah.

\section{Penyajian Data (Data Display)}

Penyajian data dilakukan dengan tujuan untuk mempermudah peneliti dalam melihat gambaran secara keseluruhan atau bagian tertentu dari penelitian. Penyajian data dilakukan dengan cara mendeskripsikan hasil wawancara yang dituangkan dalam bentuk uraian dengan teks naratif dan didukung oleh dokumendokumen, serta foto-foto maupun gambar sejenisnya untuk diadakannya suatu kesimpulan.

\section{Penarikan Kesimpulan (Concluting Drawing)}

Penarikan kesimpulan yaitu melakukan verifikasi secra terus menerus sepanjang proses penelitian berlangsung, yaitu selama proses pengumpulan data. Peneliti berusaha untuk menganalisis dan mencari pola, tema, hubungan persamaan, hal-hal yang sering timbul dalam penelitian ini penarikan kesimpulan dilakukan dengan pengambilan intisari dari rangkaian kategori hasil penelitian berdasarkan observasi dan wawancara. 


\section{HASIL PENELITIAN DAN PEMBAHASAN \\ Realiability (Handal)}

Pengertian dari Realiability (handal) adalah kemampuan untuk memberi secara tepat dan benar, jenis pelayanan yang telah dijanjikan kepada konsumen/pelanggan. Petugas Puskesmas Kembang Seri sudah melakukan pelayanan kepada masyarakat sesuai dengan SOP yang telah dibuat dengan memberikan arahan atau petunjuk administrasi pada keluarga pasien mulai dari pendaftaran pasien sampai ketempat pengobatan yang telah ditunjukan dari bukti pendaftaran di ruangan berdasarkan penyakit dan poli mana yang akan dimasuki untuk berobat. Kinerja petugas sudah maksimal untuk penyebuhan penyakit pasien dengan fungsinya masingmasing dan telah menerapkan 3S (Senyum, Salam dan Sapa) dan adapun dengan pelayanan yang ramah dan cepat tanggap.

Pelayanan yang diberikan oleh perawat cukup baik akan tetapi ketersedian obat-obatan sangat terbatas, yang menyebabkan keluarga pasien beli diluar yang diapotek dan pemberian obat pada pasien sering terlambat seharusnya diberikan jam 07 baru diberikan jam 09 ini merupakan kelalain perawat. Perawat tidak bisa mendeteksi penyakit yang ada pada pasien dia selalu didampingi oleh dokter yang jaga sedangkan dalam pengontrolan pasien yang menginap sudah cukup baik setiap beberapa jam sekali mengontrol pasien yang menginap. Pelayanan perawat kadang-kadang bagus yang dapat perawatnya yang mengerti tentang penyakit pasien dan ada beberapa perawat yang sombong dan sibuk main HP sehingga pasien kadang diabaikan apalagi perawat pilih kasih pada pasien yang pelayanan bagus apabila keluarga pasien yang kaya sedang pasien yang miskin dilayani tidak semenstinya.

Seperti yang sudah dipaparkan diatas tentang reliability(handal) maka penulis menarikkesimpulan diatas tentang pendapat perawat dan pasien. Petugas
Puskesmas Kembang Seri sudah melakukan pelayanan cukup baik sesuai dengan SOP yang telah dibuat dengan memberikan arahan atau petunjuk administrasi pada keluarga pasien mulai dari pendaftaran pasien sampai ketempat pengobatan yang telah ditunjukan dari bukti pendaftaran di ruangan berdasarkan penyakit dan poli mana yang akan dimasuki untuk berobat. Kinerja petugas sudah maksimal untuk penyebuhan penyakit pasien dengan fungsinya masingmasing dan telah menerapkan 3S (Senyum, Salam dan Sapa) dan adapun dengan pelayanan yang ramah dan cepat tanggap. Pelayanan yang diberikan oleh perawat cukup baik akan tetapi ketersedian obat-obatan sangat terbatas, yang menyebabkan keluarga pasien beli diluar yang diapotek dan pemberian obat pada pasien sering terlambat seharusnya diberikan jam 07 baru diberikan jam 09 ini merupakan kelalaian perawat. Perawat tidak bisa mendeteksi penyakit yang ada pada pasien dia selalu didampingi oleh dokter yang jaga sedangkan dalam pengontrolan pasien yang menginap sudah cukup baik setiap beberapa jam mengontrol pasien yang menginap. Pelayanan perawat kadang- kadang bagus yang dapat perawatnya yang mengerti tentang penyakit pasien.

\section{Responsiveness (Ketanggapan)}

Pengertian dari Responsiveness (Ketanggapan) adalah Kesadaran/keinginan membantu konsumen dan memberikan pelayanan yang cepat. Kesiapan petugas Puskesmas Kembang Seri sudah melayani pasien,pegawai memilikipekerjaan dimana sudah diatur dijadwalkan piketnya, mulai dari jam 8 pagi sampai jam 13.30. jam 13.30 - 17.00 WIB yang peket dan jam 17.00 WIB sudah selesai peketnya itu untuk melayani masyarakat. Standar pelayanan pada pasien sudah diatur dalam SOP dan petugas wajib menangani keluhan penyakit pasien dengan pelayanan ditangani oleh perawat sudah maksimal. Perawat yang siap siaga dalam 
memberikan pelayanan pengobatan pada pasien karena peralatan medis yang sudah tersedia. Perawat sudah cukup terampil dalam menangani penyakit pasien. Tapi ada juga perawat yang sombong dan sibuk main HP sehingga pasien kadang diabaikan apalagi perawat pilih kasih pada pasien yang pelayanan bagus apabila keluarga pasien yang kaya sedang pasien yang miskin dilayani dengan apa adanya.

\section{Assurance (Jaminan)}

Pengertian dari Assurance (Jaminan) adalah

engetahuan/wawasan, kesopan santun, kepercayaan diri dari pemberi layanan, respek terhadap konsumen. Perawat dalam mengobati pasien dengan bersikap $3 \mathrm{~S}$ (Senyum, Salam dan Sapa) dan sopan kepada pasien dalam menanyakan keluhan penyakit yang dialaminya dan selalu memberikan informasi tentang keadaan penyakit yang diderita oleh pasien dengan penjelasan yang murah dimengerti oleh pasien. ada sebagian perawat kurang ramah, dan harusnya sopan pada pasien atau keluarga pasien, perawat masih ada yang membedakan kaya dan miskin dalam melayani penyakit pasien. Ada juga perawat yang ramah dan sopan dalam memberikan pelayanan pada pasien. Perawat memberikan informasi tentang keadaan pasien terutama penyakit pasien. Keamanan di sana kurang sedikit terjamin karena jam kunjungan tidak ada batasan waktu walaupun petugas keamanan cukup terampil.

\section{Empathy(Empati)}

Pengertian dari Empathy (Empati) adalah kemauan pemberi layanan untuk melakukan pendekatan, memberi perlindungan, berusaha mengetahui keinginan dan kebutuhan konsumen. Pelayanan yang dilakukan sesuai dengan prosedur masing-masing yang telah ditunjuk bagian-bagian pelayanan pengobatan pasien. Sudah ada petunjuk arah atau arahan langsung untuk bisa menghubungi petugas pelayanan dengan komunikasi dengan cara menyesuaikan tempat kuncinya yaitu ramah dan sopan kepada pasien sehinga pasien merasa aman dan nyaman dalam pengobatanya Dan perawat siap dihubungi waktu pasien dalam keadaan darurat untuk menangani pasien. perawat mudah dihubungi karena disetiapruangan terdapat perawat yang piket penjagaan bila terjadi hal- hal yang tidak diingikan keluargapasien dapat menghubungi langsung perawat yang piket. Perawat sangat aktif dengan pasien dalam berkomunikasi pasien dapat dengan mudah berkomunikasi dengan perawat/bidan sigap mereka juga cukup ramah sehinga membuat para pasien tidak segan untuk bertanya atau sebagainya. Akan tetapi dalam segi obat-obatanya belum tersedia atau masih kurang tersedia di puskesmas yang akibatnya keluarga pasien beli sendiri di apotik seperti obatobatan,dan jarum infusyang obatnya tidak tersedia di puskesmas.

\section{Tangibles (Fasilitas Fisik)}

Pengertian dari Tangibles (fasilitas fisik) adalah penampilan pegawai dan fasilitas fisik lainnya, seperti: peralatan/perlengkapan yang menunjang pelayanan. dilihat dari fisik gedung sudah bagus, sudah terawat, bersih, nyaman karena sudah ada petugas kebersihannya. Petugas bertanggung jawab diruangannya masing-masing, perawat melaksanakan juga kerja bakti, gotong royong setiap hari jumat yaitu jumat bersih. Tetapi kerapian masih kurang dikarenakan petugas sibuk melayani pasien, sedangkan peralatan sudah cukup memadai dan lengkap untuk menangani pasien agar puas dalam berobat. Puskesmas Kembang Seri dilihat dari gedungnya sudah bagus dan ruangannya sudah cukup. ada beberapa rungan yang pasiennya terlalu banyak dihuni pasien dan masih diketemukan bau obat yang sangat menyengat yang dirasakan oleh pasien dan pengujung sedangkan kebersihannya cukup bagus tapi perlu diperbanyak tempat sampah agar tidak terjadi sampah yang berserakan. 
Peralatan medis memang masih kurang dibandingkan dengan rumah sakit tapi kalu untuk darurat sudah cukup memadai.

Hasil penelitian melalui wawancara dengan keluarga pasien menunjukkan bahwa pelayanan perawatan tersebut dapat disimpulkan bahwa pelayanan perawat di Puskesmas Kembang Seri kurang berkualitas. Hal ini terlihat dari kenyataannya bahwa perawat kurang menjaga kerapian, kebersihan penampilan dalam memberikan pelayanan keperawatan kepada pasien, kurang membantu pasien mau berobat, agak sulit untuk dihububungi, sehingga pasien yang menerima pelayanan keperawatan kurang berkualitas.

Perawat di Puskesmas Kembang Seri belum ramah tapi ada sebagian perawat yang ramah dalam melayani pasienwalaupun masih kurang cekatan, dan kurangnya inisiatif sehingga banyak yang hanya menunggu perintah dokter atau perawat senior, dalam ruangan ini juga perawat masih kurang berperan sesuai dengan fungsinya. Fungsi perawat sebagai pemberi asuhan keperawatan, pelindungan advokasi pasien, sebagai pendidik, kolborasi dengan ahli gizi, dan peran lainnya.

Perawat di Puskesmas

Kembang Seri dalam memberikan elayanan kepada pasien sudah cukup bagus walaupun ada sebagian yang masih agak cuek dengan status pasien. Pelayanan yang maksimal diberikan pada pasien yang kaya diperhatikannya dan pengobatanya sedangkan pasien yang kurang mampu sedikit ditelantarkan walaupun pelayananya setengah hati. Apalagi dokternya masih sangat terbatas mereka datang ke Puskesmas Kembang Seri ada waktu-waktu tertentu atau ada jadwalnya dia dinas tidak setiap hari berada di puskesmas tersebut. Sedangkan pada malam hari sering kali dokternya tidak ada hanya di temuai perawat yang jaga. Sehingga masyarakat atau pasien sering kali mengeluhkan tentang keberadaan dokter di Puskesmas Kembang Seri masih sangat kekurangan dokter itu pun hanya dokter umum sedangkan dokter sepesialis tidak ada sama sekali.

Puskesmas Kembang Seri dilihat dari gedung sudah memadai dan bagus akan tetapi obat-obatan masih sangat terbatas atau masih sangat kurang. Terbukti banyaknya keluarga pasien mengeluhkan masalah ini. Keluarga pasien membeli obat diluar seperti obat-obatan dan jarum infus yang sering kali diketemukan di puskesmas tidak tersedia. Masih kurangnya kerapian di puskesmas Kembang Seri masih terlihanya dirungan alat-alat berserakan dan tidak sedap dipandang mata. Alasan mereka sibuk melayani pasien sehinga untuk menata ruangan tersebut kurang ada waktu. Dan masih diketemukan ada ruangan tertentu masih terasa bau tak sedab dikarenakan bau obat-obatan yang begitu menyengat sehinga menggangu kenyamanan pasien dan pengujung dan waktu jam berkunjung. Apalagi jam berkunjung di Puskesmas Kembang Seri tidak ada batasannya jadi masyarakat yang berkujung bebas kapan pun mau berkunjung. Sedangkan peralatan medis masih kurang lengkap dibandingkan dengan rumah sakit akan tetap kalau hanya untuk segi darurat masih bisa diatasi sebelum dirujuk kerumah sakit yang lebih bagus peralatan medisnya.

\section{PENUTUP \\ Kesimpulan}

Berdasarkan uraian-uraian diatas pada bab sebelumnya telah menjelaskan bagaimana Kualitas Pelayanan Kesehatan Di Pusat Kesehatan Masyarakat (Puskesmas) Kembang Seri Kecamatan Talang Empat Kabupaten Bengkulu Tengah. Sehinga dapat ditarik kesimpulan sebagai berikut:

\section{Realiability (Handal)}

Petugas Puskesmas Kembang Seri sudah melakukan pelayanan cukp baik sesuai dengan SOP yang telah dibut dengan memberikan arahan atau petunjuk administrasi pada keluarga pasien. Sudah menerapkan $3 \mathrm{~S}$ ( 
Senyum, Salam dan Sapa) masih diketemukam perawat yang kurang ramah. Ketersedian obat- obatan sangat terbatas, yang menyebabkan keluarga pasien beli diluar dan pemberian obat pada pasien sering terlambat seharusnya diberikan jam 07 pagi baru diberikan jam 09 ini merupakan kelalain perawat.

\section{Responsiveness (Ketanggapan)}

Perawat yang siap siaga dalam memberikan pelayanan pengobatan pada pasien karena peralatan medis yang sudah tersedia. Perwat sudah cukup terampil dalam menangani penyakit pasien. Tetapi ada juaga perawat yang sombong dan sibuk main HP sendiri sehingga pasien kadang-kadang diabaikan apalagi perawat pilih kasih pada pasien dalam segi pelayanan, bagus apabila keluarga pasien yang kaya sedang pasien yang miskin dilayani dengan apa adanya.

\section{Assurance (Jaminan)}

Ada sebagian perawat kurang ramah, dan sopan pada pasien atau keluarga pasien perawat masih ada yang membedakan kaya dan miskin dalam melayani penyakit pasien. Ada juga perawat yang ramah dan sopan dalam memberikan pelayanan pada pasien. Perawat memberikan informasi tentang keadaan pasien terutama penyakit pasien. Keamanan di sana kurang sedikit terjamin karena jam kunjungan tidak ada batasan waktu walaupun petugas keamanan sudah cukup terampil.

\section{Empathy (Empati)}

Perawat mudah untuk dihubungi disetiap ruangan terdapat perawat yang jaga bila terjadi hal-hal yang tidak di ingikan keluarga pasien. Perawat sangat aktif dengan pasien dalam berkomunikasipasien dapat dengan mudah berkomunikasi dengan perawat/bidan sigap, mereka juga cukup ramah sehinga membuat para pasien tidak segan untuk bertanya atau sebagainya. Akantetapi dalam segi obat-obatan masih kurang tersedia di puskesmas tersebut pasien beli diluar terutama jarum infus.

\section{Tangibles (Fasilitas Fisik)}

Puskesmas Kembang Seri dilihat dari gedungnya sudah bagus dan ruangannya sudah cukup. Ada beberapa rungan yang pasiennya terlalu banyak dihuni pasien dan masih diketemukan bau obat yang sangat menyengat yang dirasakan oleh pasien dan pengujung sedangkan kebersihannya cukup bagus tapi perlu diperbanyak tong-tong sampah agar tidak terjadi sampah yang bersirakan. Peralatan medis memang masih kurang dibandingkan dengan rumah sakit tapi kalau untuk darurat sudah cukup memadai.

\section{Saran}

1. Perawat hendaknya selalu memperhatikan jadwal pemberian obat pada pasien jangan sampai telat memberikan obat pada pasien karena menyangkut nyawa pasien dan kesembuhan pasien.

2. Sikap perawat harus ramah dan sopan dalam melayani pasien yang berobat agar pelayanan pasien terjamin.

3. Perlu diperhatikan soal keamanan terutama tetapkan jam kunjungan keluarga pasien dalam berkunjung sehingga suasana keamanan dan kenyaman terjamin.

4. Puskesmas Kembang Seri harus menyediakan obat-obatan yang cukup terutama jarum infus agar keluarga pasien mudah mendapatkanya.

5. Bangunan fisik Puskesmas Kembang Seri sudah bagus masih ada bau obatobatan yang menyengat sehinga kurang sedap dirasakan oleh pasien dan keluarga pasien.

\section{DAFTAR PUSTAKA}

Emi, Mimin. 2004. Etika Keperawatan Aplikasi Pada Praktik. Jakarta, 
kedokteran EGC.

Hayat.2017.Manajemen Pelayanan

Publik.. Jakarta, Rajawali Pers. Jaya

Munin. 2004. Manajemen Kesehatan . Jakarta, Kedokteran EGC

Mahi, M. Hikmat. 2011. Metode Penelitian Dalam Perspektif Ilmu Komunikasi Dan Sastra. Bandung, Graha Ilmu.

Moenir. 2010Manajemen Pelayanan Umum. Jakarta, Bumi Aksara.

Muarsaroh 2010. Aspek-aspek efektifitas. Bandung. Program Pelaksanaan PNPM- MP.

Putu, $\quad$ Sudayasa. 2009.

Hakikat 5 Dasar

Pelayanan Kesehatan

Puskesmas.http://www.puskel.com/ha kikat-5-nilai-dasar-pelayanankesehatan-puskesmas.

Sinambela, lijan Poltak. 2006. Reformasi Pelayanan Publik, Teori, Kebijakan, Implementasi. Jakarta, Bumi Aksara Praptianingsi, Sri. 2007. Kedudukan
Hukum Keperawatan Dalam Upaya Pelayanan Kessehatan Di Rumah Sakit. Jakarta, PT. Raja Grapindo Persada.

Supranto. 2006. Mengukur Tingkat Kepuasa Pelanggan Atau Konsumen. Jakarta, Reneka Cipta.

Sugiyono. 2004. Metode Penelitian. Bandung, Alfabeta.

Sugiyono. 2012. Metode Pelitian Kuantitaif Kualitatif. Bandung, Alfabeta.

Sugiyono. 2014. Metode Penelitian Pendidikan Pendekatan Kuantitatf Kualtatif. Bandung, Alfabeta

Titik, Triwulan, dan Shinta Febriana.2010.Perlindungan Hukum Pada Pasien. Jakarta, Prestasi Pustaka.

Triwibowo Cecep. Ilmu Kesehtan Masyarakat. Jakarta, Trans Info Media.

Trihono.2005. Manajemen Puskesmas Berbasis Paradigma Sehat. Jakara. Cv. Sagung Seto. 